\title{
Introduction to Roman Faith and Christian Faith (OUP, 2015)
}

Teresa Morgan

The evolution of any book takes a meandering course: rising, often, out of the foothills of some other project; finding its own route through one's existing interests; winding out of familiar into increasingly unfamiliar territory until it arrives at an outfall on what may be quite an unexpected sea. One hopes then that the place will develop into a harbour, where new meetings can take place and new ideas be exchanged. I am fortunate that Roman Faith and Christian Faith has found its way to a new and multicultural space, where historians, biblical scholars, theologians, and philosophers can meet and exchange ideas of common interest.

Roman Faith arose from my existing interests in ancient history, biblical studies and early Christianity, and particularly my interests in the history of mentality and the relationship between mentality, social practices and institutions. It seeks to answer two interlocking questions: how do the attitudes and social practices encompassed by the language of pistis and fides (complex terms whose central meanings include 'trust', 'trustworthiness', 'faithfulness' and 'good faith') operate in the world of the early Roman empire? And within this world, why is pistis/fides (which in this context we often translate 'faith') uniquely important to early Christian communities?

The book begins by observing that the language of pistis/fides is central to Christianity as to no other ancient community and no other ancient or modern religious tradition. Without it, it is impossible to do justice to Christian understandings of the relationship between God, Christ and humanity. Its importance, moreover, predates our earliest records. In Paul's first letter to the Thessalonians, dated to c. 49/50 and probably the earliest book of the New Testament in its current form, pistis language appears fourteen times in five short chapters, and followers of Jesus Christ are referred to as hoi pisteuontes as if the term will already be familiar to them. Thereafter the 'pistis lexicon' (pistis and all its cognates in all forms, as opposed to the 'pistis lexeme', which consists of forms of the noun pistis) appears throughout every book of the New Testament apart from 2 John, in every layer of redaction, and more often than any of the New Testament's other key concepts including love, righteousness, salvation, and hope. 
It is therefore surprising that the reasons why pistis was so important to early Christians are almost unexamined. Biblical scholars and theologians take the importance of Christian faith, if not always its meaning, for granted (Morgan 2015, 212-443 and passim), while classicists are interested in pistis/fides in the Greek and Roman worlds in general, but not among Christians. There is, however, prima facie a question to be answered, and it prompts another, closely linked: how did early Christians understand the meaning and operation of pistis/fides? It is only when we understand this that we can properly understand why pistis was so important to Christians.

To many theologians, axiomatically, Christian faith is, from its very beginnings, sui generis both as to its object, God's saving action in Christ, and as to its twin modes of operation: what Augustine (De Trin. 13.2.5) influentially defined as fides quae and fides qua (Morgan 2015, 28-30). On this view Christian pistis/fides never shared its meaning, operation or significance with pistis or fides in the world around it. This seemed to me most unlikely to be true. As I put it in what Professor Howard-Snyder, in a recent article, dubbed 'Morgan's maxim' (Howard-Snyder 2017, 33),

communities forming themselves within an existing culture do not typically take language in common use in the world around them and immediately assign to it radical new meanings. New meanings may, and often do, evolve, but evolution takes time. This is all the more likely to be the case where the new community is a missionary one. One does not communicate effectively with potential converts by using language in a way which they will not understand. In its earliest years, therefore, we should not expect the meaning of Christian pistis (or fides) language to be wholly sui generis. We should expect those who use it to understand it within the range of meanings which are in play in the world around them... (Morgan 2015, 4)

Roman Faith set out to test the hypothesis that the meaning and operation of pistis in the earliest Christian communities, as evidenced by the writings of the New Testament, were very similar to those of pistis and fides in the contemporary GraecoRoman and Jewish worlds, that Christians evolved new understandings and practices of trust or faith only gradually, and that any explanation of the importance of pistis to Christians must take this into account. The book took a 'history of mentality' 
approach: surveying the surviving literary, papyrological and epigraphic sources of the period (c.100 BCE to $200 \mathrm{CE}$ ) to identify large-scale patterns of thinking, and reading a large number of texts (including all the New Testament texts) closely, to identify distinctive ideas about pistis/fides in influential individual writings. To inform this approach it drew on recent writing in the sociology, anthropology, philosophy, economics, management theory and modern historiography of trust, all fields in which important work has been published in recent years. Particularly stimulating was the idea, recently developed in anthropology and early modern history, that the shape of trust and related concepts and practices is unique to the community in which it operates, forming a distinctive pattern based on who trusts, or does not trust, or finds it difficult to trust, whom and what, on what grounds, and to what ends (Morgan 2015, 22-3). The shape of pistis/fides in the different communities under scrutiny became one of the study's focal points.

After the Introduction, the first three chapters of the book discuss the Greek and Latin speaking societies of the late Hellenistic and early imperial worlds. They explore who trusted whom or what, and on what basis; when and why pistis/fides was easy or difficult to achieve; and, in the latter case, how fragile human trust could be deferred to more trustworthy objects or relationships (such as divinities) and how it could be reified into objects of shared trust (such as oaths or legal documents). These chapters discuss pistis/fides in oneself and pistis and fides relationships in the household, among masters and slaves, among friends, patrons and clients, in rhetoric, in gossip and hearsay, and in literary discourse; in the military, politics, inter-state relations, economic activity, in the law, at the foundations of states, and in times of crisis, and, last but not least, between human beings and gods. They conclude that pistis/fides was always important, but the degree to which it was seen as reliable varied significantly. Oneself and the evidence of one's senses, for example, are widely regarded as relatively trustworthy at this period. So, on the whole, are family members, including slaves, and experts in any field. Friends, in contrast, are rarely presented as wholly trustworthy, however desirable trustworthiness may be in principle - a source of detectable distress to many writers. Laws and magistrates attract perhaps unexpectedly strong trust, but kings and emperors little or none. Most strikingly, in almost every human situation, trust is to some degree fragile and contestable, cut with mistrust, doubt, fear or scepticism. I explored the ways in which agents in the early principate sought to palliate the defects of pistis/fides by 
'deferring' trust and 'reifying' it. For example, one might defer trust in a rumour to the production of evidence, or trust in a friend to proof, at some future point, of her goodwill. If my friend and I find it difficult to trust one another, we might reify the trust we wish to have in an oath, a credit agreement, or a legal trust: an object which we both find easier to trust than we do one another.

Chapter 4 deals with divine-human trust in Greek and Roman religiosity. It argues that there is more evidence for pistis/fides in Greek and Roman divine-human relations than historians usually assume. In particular, there is a certain amount of evidence that the gods are seen as trustworthy by human beings and that it is widely seen as appropriate that human beings should trust the gods. At the same time, the evidence of this period suggests that propositional belief in the gods is more difficult than trust, especially when one begins to examine the bases in which one might believe propositions. Of the bases for pistis/fides that are canvassed in our sources, personal experience (for instance in dreams or visions), and tradition are both treated as relatively secure. Reason and report are less so, and a persistent concern is detectable about the difficulty of detecting false beliefs. Above all, belief in the trustworthiness of the gods is based on foundationalist and coherentist claims about the nature of the world. As Cicero puts it in On the Nature of the Gods, the gods must be able and willing to help us, because if they are not, our piety is hollow and pointless, and if we abandon piety, justice, good faith, and society itself cannot stand $(1.2 .3-4)$. This is no cynical functionalist statement that religion shores up society. It attests, rather, Cicero's sense that his society's understanding of the gods and of itself are so intertwined that if it abandoned one it would lose both and collapse.

Greek and Roman religious thinking shares with Hellenistic Judaism another feature of divine-human pistis/fides: that human beings' shared trust in the divine and its trustworthiness enables human beings to trust one another. This finding came into focus when it emerged, surprisingly, that it is not true of early Christianity. Christians are regularly told to love one another and live in peace with one another, but they are never told, simply as community members, to trust one another.

Outside the Septuagint and the works of Philo and Josephus, relatively little language of pistis/fides survives from Hellenistic Jewish sources. Philo's use of pistis is mainly in line with that of other Platonists in this period, and Josephus' mainly in line with that of other Greek historians, so they are discussed alongside their Greek 
peers. Chapter 5, on the Septuagint, traces the evolution of pistis from the Pentateuch to the Hellenistic wisdom books.

In Genesis and Exodus, divine-human pistis can is presented as closely analogous to intra-human pistis, except that God is consistently trustworthy. Divinehuman pistis evolves gradually, through initiatives of trust, doubt, assurances, proofs and reifications of trust on both sides, to create new relationships which, over time, foster the development of the people of Israel. By the Hellenistic period, divinehuman and intra-human trust are diverging. Trust in God becomes a non-negotiable obligation for human beings, even if it brings no positive consequences in their lifetime. Israelites' main reassurance, if pistis needs one, lies in scripture and tradition, which affirm that God has never let Israel down, and the Deuteronomic law, which comes from God and confirms Israel's covenant with God. If the Lord sometimes seems distant, and trust in the Lord a challenge, the Lord's commandments provide a way of expressing daily one's trust and faithfulness towards God. These developments in Hellenistic Jewish pistis are significant not least as forming part of the immediate context of emerging Christianity.

The heart of the book consists of five chapters on the writings of the New Testament: two on Paul, one on most of the other epistles, one on the synoptic gospels and Acts, and one on the Johannine corpus. These offer close readings of all the New Testament passages in which pistis language occurs and extended engagement with the history of exegesis, which is dense and often conflicted. They discuss Christianity both in its own right, and as a rare example of a new community in evolution within the ancient world from which we have a rich insider perspective.

At the start of the project I was particularly interested in the overall shape of pistis in primitive Christian communities; in where pistis is perceived as easy or difficult to enact, in where it is cut with mistrust, doubt, fear or scepticism, and in the bases on which people put their trust or believed in God and Christ. By the end I was equally struck by the way different writers use pistis language to express the different ways in which they understand the nature and actions of Jesus Christ. In more than one writer an unsuspected connection emerged between pistis and predestination. Almost every writer presented some form of what I called a 'cascade' of pistis, flowing from God, through Christ and the apostles to community leaders and community members. This last finding liberates pistis from the silo which it has long inhabited as a 'theological virtue', making clear that it is not only theological but, 
equally significantly, ethical, shaping both divine-human relations and intra-human relations and social practices, ecclesiological, shaping the structure of primitive churches as institutions, and eschatological, shaping images of what the faithful hope for in the kingdom of God.

Among the themes which the book emphasizes are that throughout New Testament writings, pistis is more strongly relational than cognitive, a theme to which the following papers will return. It argues that the 'cascade' of trust not only gives the apostles their authority as preachers and baptizers, entrusted by Christ with the gospel (cf. 1 Thess. 2.4), but creates the earliest institutional structures of the church. It seeks to trace where Christians' fascination with the concept and practice of pistis begins, and conclude that it may have derived in part (though probably not only) from the teaching of Jesus himself.

New Testament writers use pistis language in different ways to explore where to locate Christ, the new factor, in their inherited model of divine-human relations. John, for example, uses the verb pistuein in passages that emphasize the identity of Christ with God: 'Believe in God, believe also in me.' (14.1). The synoptic gospels use it when they want to emphasize the mobility of Christ between earth and heaven. People who come to Jesus to be healed, for instance, in the synoptic gospels, seem to approach what they see as a rabbi who can heal them, and encounter the Messiah who can also save them. Paul, meanwhile, draws on secular uses of pistis language in political diplomacy to locate Christ equidistantly between God and humanity as the one who reconciles them.

The argument draws a contrast between most New Testament writers, for whom pistis is an act of trust/belief based on their encounter with Christ, and John, for whom pisteuein is the act of recognizing that one has (already) been given eternal life and a response to that recognition. It also emphasises that very early Christians show no signs of thinking of pistis as a deliberately non-rational 'leap of faith' in the modern, fideist sense. On the contrary, all the writers of the New Testament take some pains to explain (what they understand as) the firm bases on which people pisteuein: whether direct encounter with Christ, witnessing of miracles, or experience of the power of the Spirit.

Two final chapters draw the threads of Greek, Roman, Jewish and Christian religiosity together to look at some areas where I argue they have much in common. All are more interested in the relationality of pistis/fides than its interiority. Interiority 
in faith, I conclude, developed as part of Christian pistis between the early second century and the fifth. Christianity also shares, with classical and Jewish depictions of aboriginal and eschatological golden ages, Jewish and Christian visions of heaven, insider and outsider descriptions of some 'elective' Greek and Roman cults, and Stoic communities of good men, that pistis, together with other 'virtues' or divine and divinely-given qualities and practices, forms part of the structure of the remembered or hoped-for ideal divine-human society. Across the ancient Mediterranean, pistis/fides is structural to ideal socio-political collectives: foundational to the way people thought societies should be.

I hope this gives some flavour of the book. The papers that follow focus in more detail on some of the questions that arise from it.

\section{References}

Howard-Snyder, D. (2017). Markan Faith, International Journal for Philosophy of Religion 81.1: 31-60.

Morgan, T. (2015). Roman Faith and Christian Faith. Oxford: Oxford University Press. 


\title{
Response to Papers on Roman Faith and Christian Faith
}

\author{
Teresa Morgan
}

I am grateful to Professors Driediger-Murphy, McKaughan and Howard-Snyder for reading Roman Faith and Christian Faith so carefully, thinking about it so interestingly, and challenging me to think further about some important issues. This essay responds broadly in the order of their papers, though some of their interests, and my responses, overlap.

Professor Driediger-Murphy raises a number of questions based on what she rightly identifies as three key aims of the book: to shift our understanding of what Greeks, Romans, Jews and Christians did and did not have in common; to help us rethink what is distinctive about Christian pistis/fides; and to resolve a disconnect between scholars in different disciplines. Professor Driediger-Murphy's questions share significant points of interest with those of Professor Howard-Snyder, Professor McKaughan, and others who are currently seeking to develop our understanding of faith from the perspective of analytical philosophy. In particular, all three seek to refine our understanding of the cognitive aspect of faith. They ask what role cognition plays in faith (whether in Greek and Roman religions or Christianity), whether cognition's role changes over time, and if it does, how and why. What is involved in cognition: does faith, for example, necessarily involve commitment to propositions? If it does, do ancient writers, including writers of the New Testament, require any particular attitude (such as belief, hope, or trust) towards such propositions?

Professor Driediger-Murphy's first question is whether non-Christians from the second century onwards were right to see Christians as depending more heavily than themselves on fideism, in the sense of a 'leap of faith' that does not depend on practical demonstrations or logical proofs of the thing that is believed. If so, what caused the change? This a crucial question which goes well beyond Roman Faith. It has not been asked, let alone answered systematically for the patristic period (for which there are remarkably few studies of pistis/fides or 'faith' in general). To do it justice one would need to examine the full range of literary, documentary, visual and material evidence for the period; to consider the possibility that understandings and practices of faith varied in different regions, communities, or contexts within 
communities; to investigate how and why certain forms of cognition, together with the concept of faith as a state of mind or heart, became more important over time (Morgan 2015, 11-12, 14); and to consider what is involved in cognition in a wide range of authors who differ from one another.

These and related questions are the subject of my forthcoming monograph, The Invention of Faith, which seeks to explain how and why Christian pistis/fides evolved (as it clearly did) from the first century to the fifth, and what impact evolved Christian understandings and practices had on the Christianized later Roman empire. Among other themes, I will argue that during this period Christian faith developed many of the cognitive and affective aspects with which we still associate it, including a greater emphasis on fideism. For now, I will try to offer the beginnings of an answer to Professor Driediger-Murphy's question.

Non-Christians undoubtedly were, to some extent, justified in observing that Christians of the immediately post-apostolic era did not rely heavily on either logical proofs or demonstrations (though through later antiquity into the mediaeval world, logic would play a growing role in theology). In this, Christianity seems to have evolved somewhat since its earliest years. In the New Testament we regularly find writers appealing, for instance, to the apostles' witness to the resurrection, the evidence of Jesus's followers' own eyes, and converts' experience of the power of the spirit as a basis for pistis towards God and Christ (Morgan 2015, 241-6, 354-65). From the early second century, we find writers appealing increasingly to tradition rather than witness, and report rather than direct evidence (though personal experience of the spirit remains a powerful basis for faith).

It is worth noting that in attacking Christians for not relying on proofs or demonstrations, non-Christians were being more than a little disingenuous. Tradition and report, as bases of pistis/fides towards the gods, are also invoked regularly and unproblematically by non-Christians (Morgan 2015, 145-51). In some respects the evolution of Christianity was bringing it closer to other cults.

Where Christianity was becoming genuinely distinctive was in its increasing use of tradition and report specifically to support propositional beliefs about God and Christ. (I use 'propositional belief', here and throughout, as in Roman Faith to refer to the conviction that certain propositions are true, without necessarily specifying whether the attitude involved is, for instance, trust, hope, or what philosophers would call an attitude of belief. We will return below to the question what attitudes are 
involved in these beliefs.) (Some) non-Christians found this challenging, probably because they found propositional belief in the divine challenging in general. Roman Faith shows (pp. 142-5) that although pistis/fides in the sense of trust in the gods is strong and widespread in the world of the first century, propositional beliefs tend to be problematized. It suggests that this is because '[p]ropositional belief demands grounds and reasons. But when one ponders one's reasons for believing something about the gods, they soon begin to seem fragile' (p. 145). Arguments and proofs for the existence or nature of the divine are usually problematized by intellectuals, so it is not surprising that there are signs of tension in this period between the relative ease with which worshippers pursued good relations with the gods, and the difficulties philosophers encountered in thinking propositionally about the divine. It suggests, however, that when non-Christians accused Christians of irrational fideism, the real issue was less Christians' reliance on tradition and report as such, than their willingness to use both as a basis for propositional belief, and, in general, their increasing interest in propositional belief at a time when some (some) educated Greeks and Romans were struggling with it.

The beginnings of this change are already detectable in some of the later books of the New Testament. The undisputed letters of Paul, for example, describe community members as putting their trust in God and Christ on the basis of Paul's and the other apostles' direct experience of Christ (e.g. 1 Cor. 15.1-5, 2 Cor. 12.1-10), the power of the spirit which he communicates because he has been entrusted with the gospel (e.g. 1 Thess. 1.5, 2.3), and their own experience of the spirit when they heard the gospel (e.g. 1 Thess. 1.9, 2.10-11, 5.2). The Pauline letter to Titus offers a slightly different account. Titus is told that a community elder should be someone who holds fast to the pistos logos, the 'trustworthy word' or 'discourse', according to the teaching he has received (1.9), so that he himself will be able to exhort others with 'sound teaching' and 'refute opponents' (cf. 3.8).

Titus' emphasis is less on the experience of the apostle who preached the good news, or Titus' experience of the power of receiving it as the basis of pistis, than on the word itself. Trusting or believing in a word or discourse, however, has a more strongly cognitive, even propositional aspect than trusting or believing in a person. The same shift is visible in relation to the content of the good news. Compare what Titus says with the way Paul refers to the content of his preaching when it has come into question. Criticizing the Corinthians for listening to other preachers, Paul says, 'It 
has been reported ... that there are rivalries among you ... each of you is saying, "I belong to Paul," or "I belong to Apollos"...' (1 Cor. 1.11-12). Chastising the Galatians for the same reason, he says, 'I am amazed that you are so quickly forsaking the one who called you by grace...' (Gal. 1.6) The focus in these passages is on the Corinthians' and Galatians' abandonment of a relationship, not on their wrong interpretation of a discourse (though no doubt something of both was involved). In Titus, the emphasis is reversed.

Titus is written as if by Paul, but I share the view of many scholars that it is pseudepigraphical, and this helps to explain its understanding of the nature and basis of pistis. After the deaths of the first generation of apostles, who knew Jesus in life and/or witnessed the resurrection, community leaders needed to find new bases for members' pistis and their own authority. What survived of the apostles' missions were memory, oral tradition, and (increasingly) written reminders of what they said. These became a new source and focus of authority. Belief in words, though, is not the same as belief in a person; something of the relationality of pistis has been lost.

The Letter to Titus also hints at another cause of the shift towards propositionality: disputes between Christian groups. This theme emerges even more clearly in other late biblical epistles, notably in the Johannine letters.

1 John has a strikingly propositional character. Unlike any other New Testament letter, it begins with a proclamation rather than a greeting and proclamations recur throughout. The importance of believing certain things about Jesus Christ is summed up twice at the start of Chapter 5: 'Everyone who trusts/believes that (pas ho pisteuōn hoti) Jesus is the Christ is begotten by God...' (5.1); 'Who is the victor over the world but the one who trusts/believes that Jesus is the Son of God?' (5.5). All the author's statements about the importance of believing or affirming certain things about Jesus Christ come in the context of one of this letter's main preoccupations: battling the Antichrist and identifying those who are inspired by him. Propositional language comes to the fore when what is at issue are the differences between communities, and who is right and who wrong.

The earliest non-testamental letters reveal a little more of this evolution. Some examples are discussed in Roman Faith (pp. 512-4) and I will not repeat them here, but they underline that it is often in the context of conflict between Christians and groups or between Christians and (those identified by others as) non-Christians that propositionality to the fore. 
These examples reveal the beginnings of developments in Christian religiosity which would lead to major changes in the tradition. I have yet to complete the work which will trace the paths of change through the next three centuries, but wherever we find concerns about authority or doctrinal disputes, we can expect to find evolutions in understandings of pistis/fides which do not abandon the relational altogether but which bring the propositional increasingly into prominence. ${ }^{i}$

So far I have not tackled the question whether pistis/fides necessarily involves a commitment to propositions, and if it does, whether ancient writers, including writers of the New Testament, require any particular attitude (such as belief, hope, or trust) towards propositions. I will return to this, but first I turn to another question from Professor Driediger-Murphy: was the idea, for which I have argued, that early Christians are told to place pistis/fides in God but not in one another as community members, one reason why Christians seemed periodically so threatening to the community at large? This is a very attractive hypothesis. It cannot be the only reason (nor does Professor Driediger-Murphy suggest it is). Christians put their trust only in the 'living and true God' and are therefore, in relation to all the other gods, what contemporaries call atheists, and they proclaim the coming kingdom of God, which sounds potentially politically subversive. In the Graeco-Roman world, however, pistis and fides are by no means due only to rulers: they are also fundamental to good social relations of all kinds. When, therefore, Christian apologists feel compelled to claim, as they often do (e.g. Justin, Apol. 1.7, Tert. Apol. 1-3), that they are not bad citizens, it is surely possible that they seek to present themselves, against what might seem to be their interpretation of pistis/fides, not only as loyal subjects of the emperor, but also as good participants in civil society.

I turn next to Professor McKaughan's paper, and its central concern: whether early Christian discourses represent or demand an attitude of belief. Do writers of the New Testament represent an attitude of belief as a part of believers' response to the gospel? Do they go further and indicate that it must be involved, alongside trust and other relational aspects of pistis?

1 Corinthians 15.1-5 is an important text for many reasons, not least because it is perhaps the most strongly propositional passage involving pistis language in Paul's letters. 
Now I am reminding you, brothers, of the gospel I preached to you, which you indeed received and in which you also stand. Through it you are also being saved, if you hold fast to the word $(\log o s)$ I preached to you, unless you trusted/believed in vain. For I handed on to you as of first importance what I also received: that Christ died for our sins in accordance with the scriptures; that he was buried; that he was raised on the third day in accordance with the scriptures; that he appeared to Kephas, then to the twelve ... Last of all, as to one born abnormally, he appeared to me ... (1 Cor. $15.1-5,8$, transl. NAB)

These verses evidently have a propositional aspect, in the sense in which Roman Faith used the term. Verses 3-5 read naturally as a series of propositions, and Paul talks of the logos which he received, using a verb (paralambanein, vv, 1, 3) which is regularly used of the transmission of stories and traditions. Paul therefore places himself here, unusually, more in the position of the author of the Letter to Titus than that of a first generation apostle (though in vv. 8-9 he will identify himself more closely with the first apostles). As noted above, belief in words handed down tends to be more propositional and less relational than belief in a person who is communicating their own experience of Christ.

Roman Faith argued that this passage, and the verses which come after it, are less straightforwardly propositional than they look at first sight (pp. 229-32). They also describe a relationship with God and Christ which is based on grace (cf. 15.10) and which leads to release from sin and the creation of a new divine-human community in God's kingdom. Pistis is therefore relational and situational as well as cognitive. (I observed that this is consistent with accounts of the kerygma elsewhere, and argued, in general, that trust and propositional belief are always intertwined in pistis/fides language (e.g. pp. 19-22), so there is nothing unusual about this in its firstcentury context.)

Can we go further and say that Paul demands an attitude of belief (as opposed, for instance, to one of trust or hope) to these propositions? I cannot see anything in Paul's language which allows us to argue one way or the other: nothing indicates that he was thinking in terms of such fine distinctions. If we ask whether Paul himself had an attitude of belief to these propositions, again, his language does not tell us, though it would take a dramatic - surely, to most scholars, an implausible - shift in our 
understanding of him and his mission to imagine that he did not. To determine whether Paul ever distinguishes between attitudes would require investigation of his writings as a whole, which is beyond the scope of this paper. I am doubtful that a wider analysis would show that Paul ever makes such fine distinctions, but the question remains open for now.

If we widened the search, could we identify passages elsewhere in the New Testament in which an attitude of belief demonstrably either was or was not involved? A thorough investigation is again beyond the scope of this paper, but I have not yet identified a New Testament passage in which I would argue that belief is demonstrably uninvolved. One possible candidate might be the mysterious affirmation of the father of the boy with a demon at Mark 9.24: 'pisteuō; help me in my apistia.' One might choose to interpret that outcry as meaning, 'I hope (or 'trust') that you can help my son [without having an attitude of belief]; help me to believe it.' It could, though, equally well mean 'I believe that you can exorcise my son; help me to trust you', or 'I believe and hope/trust that you can help my son [but not as strongly as I might]; help me to believe and hope/trust more.' Any of these would make sense in the immediate context and none, as far as I can see, would be impossible in Markan theology, but we have no way of deciding between them.

This in itself may be significant. Mark and other New Testament writers, like Paul (and writers of this period in general), simply do not use pistis/fides language with the precision of modern analytical philosophers, and distinguish clearly between possible attitudes implied in pistis/fides. This also suggests an answer to Professor McKaughan's question whether New Testament writers assume that propositional belief must be involved, alongside trust and other relational aspects of pistis. If New Testament writers provide no firm evidence of whether belief is involved in faith, $a$ fortiori they cannot tell us whether it must be.

We may be able to make a little more headway with a slightly different question which deserves attention in its own right. Is it, for New Testament writers, possible to have an appropriate, effective pistis, for instance towards Christ, without having right beliefs about him? If it is possible to have faith without understanding Christ rightly, then we may suspect (though this does not in itself prove) that an attitude of belief is not always essential in New Testament pistis, because common sense suggests that it is unlikely that a New Testament writer would think it essential 
for the faithful to have an attitude of belief in Christ in the event that the content of that belief was wrong.

In Roman Faith (pp. 359-61, 365) I argued that the synoptic gospels sometimes use pistis language to mark moments when someone, such as the woman with a haemorrhage or the Roman centurion, puts his or her trust in Jesus, believing or hoping that he is a healer, and encounters not only physical healing but salvation. We cannot be sure whether pistis here involves an attitude of belief, but if it does, the gospels strongly suggest that the content of the belief is not right, or not entirely (there is no sign that the woman or the centurion recognizes Jesus as the Messiah). Nevertheless, the pistis involved is clearly powerful and effective: in Mk 5.34 Jesus tells the woman with the haemorrhage that it has saved her. That such stories are told several times in the gospels suggests that pistis such as that of the woman or the centurion is acceptable and appropriate - even exemplary - even if it involves little or nothing of what a modern philosopher would identify as an attitude of belief in Christ as saviour.

The gospel of John offers an account of the content of what people believe which is famously elusive. As Bultmann put it, in a much-quoted passage of his commentary, the 'central intuition' of the gospel

must lie in the constantly repeated proposition that Jesus is the emissary of God (e.g. 17.3, 17.23, 17.25), who through his words and deeds brings revelation. He performs the works given him by the Father, he speaks what he has heard from the Father or what he has seen in his presence. The man who believes is saved, he who does not is lost. But there lies the riddle. Precisely what does the Jesus of John's Gospel reveal? One thing only, though put in different ways: that he has been sent as Revealer. (transl. Ashton 1991, 53, emphasis original.)

When John's Jesus says, for instance, 'Believe in God, believe also in me' (14.1), the propositional content of this belief remains a riddle. In Roman Faith I argued that John plays constantly with what looks like propositional language in order to underline that knowing Jesus is in fact a matter of relationship (p. 429), and that those who seek to know something about Jesus, like the Pharisees, simply show by that token that they are not among the elect (pp. 425-32). What the elect believe, or know (the two lexica are often interchangeable) is above all God and Jesus themselves, not 
anything specific about them. Whether or not an attitude of belief is involved in Johannine pisteuein, therefore, John's deliberate vagueness about its content and criticism of those who want to know about Jesus strongly suggests that it is less important than his readers might expect.

In these examples, an attitude of belief may be involved in pistis, but it may be wrong; it may be changeable or elusive; and all the gospel writers, in different ways, suggest that the relationship between God, Christ and the characters concerned does not depend on it. We cannot say of any of these passages that an attitude of belief is definitely excluded, but they do hint that for some early Christian writers, at least, it is not always a sine qua non of faith, central to it, or even essential to it.

We must, of course, distinguish between characters who appear in the gospels and the early Christians who listened to them. It is possible that a form of pistis which was portrayed as acceptable in Jesus's lifetime, while his Messianic identity was not widely recognized or was even a secret, would not have been acceptable in early Christian communities. Against this is the apparently exemplary character of so many of those who encountered Jesus in his lifetime. It would surely be odd and confusing to early Christians to find a form of faith represented and validated in the gospels that was forbidden to them.

We must also recognize variations between New Testament writers. To judge by 1 Cor. 15.1-5, Paul is more concerned with propositional belief than any of the gospel writers. (In light of the earlier point about the post-apostolic generation, this may be because he did not encounter Jesus in life; Paul is both, as he calls himself, the last of the apostles and the first of the post-apostolic generation. The writers of the gospels presumably did not encounter Jesus in life either, but I have argued (2015, p. 362) that one of the aims of the gospels is to recreate for later followers something of the experience of encountering Jesus in his lifetime.) At the least, however, the passages we have briefly discussed suggest that having an attitude of belief towards propositions is not, for New Testament writers, central to pistis, and it may not always be essential.

Professor McKaughan also raises the question whether a study like Roman Faith which focused more on the Hebrew Bible and ancient Israel would show that they emphasized even more strongly the 'fidelity/faithfulness/loyalty/allegiance side of the register'. His view, developed at greater length elsewhere (McKaughan 2017) is that it would. Up to a point I agree, but I would follow John Barton's recent, 
magisterial study Ethics in Ancient Israel in drawing a slightly different picture.

Barton observes that he'emin lacks a strong dimension of 'belief', the nearest Hebrew comes to expressing propositional belief being probably the phrase 'to say in one's heart' (pp. 165-6), and notes that faith in the fideist sense is 'not very important in the Hebrew Bible' (p. 167). (In this he underlines two of the respects in which Christianity departs furthest from its Jewish inheritance.) He also discusses the verb ' $m n$ and its relatives (Barton 2014, 118, cf. 116-20, 241-2), noting the importance of their aspects of faithfulness and loyalty, but also their meanings of reliability, solidity, confidence, and trustworthiness. God is reliably faithful and the Israelites can rest on his solidity in confidence (or, as Isa. 7.9b puts it, challengingly, 'If you do not stand firm in faith (ta'aminu), you will not stand (ta'amenu) at all').

In Roman Faith I noted how often 'emunah language is translated in the Septuagint with the alettheia rather than the pistis lexicon, especially with reference to God (e.g. p. 188 n. 37). This testifies to a strong sense not just that God speaks truth (though, of course, God does), but of the reality of God and the rightness of worshipping God (cf. 1 Thess. 1.9 on the 'living and true' God). New Testament writers occasionally use the language of alètheia of God where pistis might seem equally appropriate, but they use pistis language much more often. In these passages, Christians appear to be more interested in marking God's fidelity and faithfulness than God's truth. On this showing, trust and faithfulness are fundamental both to New Testament pistis and to the Hebrew Bible. Beyond this central range of meanings, the Jewish scriptures, in Hebrew and Greek, and the New Testament part company in several directions.

Professor Howard-Snyder is also concerned, in this and other recent papers (e.g. Howard-Snyder 2013, 2017, Rice, McKaughan \& Howard-Snyder 2017), with the attitude of belief. His first question probes the relationship between attitudes of belief and doubt in pistis. For New Testament writers, specifically, must pistis consist in an attitude of belief towards certain propositions, or can it coexist with a kind and degree of doubt or scepticism that precludes such belief? Professor Howard-Snyder rightly notes that Roman Faith claims that pistis/fides is almost always cut with fear, doubt, mistrust and scepticism. He also notes that on occasions in the New Testament pistis seems to be presented as precluding mistrust or disbelief.

We have already seen that faith may not always, for New Testament writers, involve an attitude of belief. It would not be surprising if fear, doubt or scepticism 
existed in some situations in which a person did not believe or did not have pistis. But can pistis coexist with fear, doubt or scepticism? If it can, can we establish whether or not pistis then involves an attitude of belief?

There is abundant evidence that persons in New Testament writings who are described as having pistis can, in some contexts, be described as fearing or doubting, or as needing to progress in pistis (which might mean that they have emotions or attitudes which are ideally incompatible with pistis: so e.g. 2015, 222-3). Roman Faith argues, for instance, that in the synoptic gospels, Jesus implicitly recognizes that his followers' pistis is a work in progress. He occasionally rebukes them for apistia or oligopistia, but in much milder terms than those in which he attacks people who have not put their trust in him at all, and failures of pistis never cause him to expel anyone from the group (pp. 356-7).

(We might, incidentally, wonder why is it implicitly acceptable that the disciples' pistis is imperfect. One possibility is that these stories remember genuine fears and uncertainties of Jesus's followers during his lifetime. Another is that the gospel stories offer models for the encouragement of later followers; a third that it is acceptable because listeners know that these stories have a triumphant ending. Apart from Judas, the disciples do eventually, beyond the end of the gospels themselves, become exemplars of unshakeable faith, even to their own deaths, and this may make stories of their early struggles less problematic to later Christians.)

Where pistis appears in a story alongside fear or doubt, do they coexist or do they, for instance, alternate? Again, a full investigation is beyond the scope of this essay, but Matthew's story of Peter's attempt to walk on water (Mt. 14.22-33), which uses the language of faith, fear and doubt in close proximity, offers a promising case study. The disciples are at sea when they see Jesus walking towards them over the water. They are terrified (etarachthessan, v. 26), thinking that he is a ghost, and cry out in fear (phobos, v. 26). Jesus tells them not to be afraid and Peter says, 'Lord, if it is you, command me to come to you on the water.' (v. 28) Jesus does; Peter steps out of the boat and walks, but becomes frightened (ephobèthe, v. 30) and starts to sink. Jesus, says, 'O you of little faith (oligopiste, v. 31), why did you doubt (edistasas, v. 31)?' He catches Peter before he sinks, whereon the other disciples in the boat bow to him, saying, 'Truly, you are the Son of God' (v. 33).

In the first part of the story, fear dominates and pistis does not appear. In vv. 28-31, Peter's confidence (whether cognitive or affective) seems to give way to fear, 
causing him to sink. At v. 31, however, Jesus treats Peter's doubt as simultaneous with - even a description of - his oligopistia. Matthew's Jesus uses oligopistos in contexts where the disciples' pistis is imperfect, but not non-existent $(2015,336-70)$, so it seems likely that for Matthew, doubt (and probably fear) coexist here with pistis, if not with perfect pistis. Moreover, Peter's failure of pistis involves a doubt either that Jesus is real, or that the real Jesus can enable him to walk on water, or even, if the other disciples' words affirm what Peter should have believed throughout, that Jesus is the Son of God, or more than one of these, so his pistis evidently has a propositional dimension.

Does Peter's pistis in this passage involve an attitude of belief? At v. 28 Peter says, 'Lord, if it is you, command me to come to you on the water.' No attitude of belief is required here: Peter is not sure whether the figure is Jesus, and if it is, he implies that Jesus can enable him to walk on water simply by commanding it, whatever Peter's attitude. What makes Peter sink is said to be fear, not the state of his attitude of belief. Jesus then accuses Peter of doubting. Distazein can mean 'to doubt' or 'to hesitate'; it can be used of cognitive doubt, but also of something more instinctual or emotional. At no point in this passage, therefore, can we be certain that an attitude of belief is involved. Nor, however, can we be certain that it is not.

Is Paul as tolerant as the synoptic gospels of doubt, fear (excluding appropriate fear of God) or scepticism among the faithful, and does he represent any of them as coexisting with an attitude of belief? Paul can praise communities for their faithfulness (e.g. Phil. 1.3-6, 1 Thess. 1.3, 7) while recognizing that human pistis is not necessarily perfect and has scope to grow (e.g. 1 Thess. 1.2-3, 3.10). We cannot, though, be sure what kinds of pistis are involved in these passages or why in the second case it is not perfect (are the Thessalonians fearful, doubtful, ignorant, inconsistent in practice or something else?). Paul also confesses to being imperfect in pistis himself. He came to the Corinthians 'in weakness and fear and much trembling' (1 Cor. 2.3) despite his spiritual power (v. 4), so he recognizes that fear and unspecified imperfections can alternate, if not coexist with pistis, but again, we cannot be sure in what sense of pistis.

Unlike the synoptic gospels, Paul keeps the language of apistia for noncommunity members and does not use the language of oligopistia at all, ${ }^{\text {ii }}$ but in a few passages (e.g. 1 Cor. 1.11-12, Gal. 1.6-9), as noted, he does criticize community members sharply for listening to different apostles. These passages are interesting 
because, though they do not feature pistis language, it seems clear that the Corinthians and Galatians are being misled into doubt or even (if they have already forsaken Paul) scepticism about Paul's preaching.

I am amazed that you are so quickly forsaking the one who called you by grace for a different gospel (not that there is another). But there are some who are disturbing (tarrasontes) you and wish to misrepresent (metastrepsai) the gospel of Christ. But even if we or an angel from heaven should preach a gospel other than the one that we preached to you, let that one be accursed (anathema)! (Gal. 1.6-8)

The language of disturbance, misrepresentation and anathema is strong and unambiguous: Paul is not only vexed that the Galatians are listening to other apostles; he is certain that what they are hearing is wrong. A few verses later (1.23), Paul reports other Christians as saying of him, 'The one who was persecuting us is now preaching the pistis he once tried to destroy.' I have argued $(2015,265-7)$ that pistis here must mean 'the relationship of trust between God, Christ and human beings' rather than the dogmatic content of the gospel. But even if what is at issue is a right or wrong relationship (rather than, for instance, a right or wrong view of the nature of Christ), and leaving aside how the Galatians were misled (which we do not know), Paul's claim that one can distinguish these relationships as right or wrong suggests that there is a cognitive and propositional aspect to choosing a particular pistis, and only those who make the right choice are adhering to the gospel.

Must those who choose the right pistis, though, have an attitude of belief towards it rather than, for instance, one of hope? As I noted above in relation to 1 Cor. 15, it will be hard for most biblical scholars to imagine that Paul does not himself have an attitude of belief towards his gospel and the pistis it preaches, nor to assume that he does not demand the same of the Galatians. But here as in 1 Corinthians, Paul himself does not make the distinction and his language is not fine grained enough to reveal one, so we cannot be sure.

These examples are necessarily brief, and they point to the need to do more work, but I am grateful to Professors McKaughan and Howard-Snyder for prompting me think further about these passages and these issues. 
Prof. Howard-Snyder's third question concerns Saint Teresa of Calcutta, and the nature of her faith. 'Would people in the early Roman Empire and the early churches tend to see Saint Teresa as (i) someone who lacked faith in God/Jesus/the basic Christian story, (ii) someone who merely had faith in God/Jesus/the basic Christian story, or (iii) someone who not only had faith in God/Jesus/the story but who was an exemplar of such faith?'

I will raise and set aside here an issue which is important but which this discussion does not tackle. Belief in a narrative is not the same thing as belief in propositions, and it is the latter that is the focus of these papers. When Professor Howard-Snyder refers to the 'basic Christian story', I therefore take him for present purposes to be talking about Saint Teresa's belief, for instance, that Christ rose from the dead.

The answer to his question in very early churches would surely depend on which writer one referred to, and how Teresa's story was told and heard. If, for instance, Teresa were writing to Paul about her doubts, then on the basis of the argument above, he might chastise her under option (i) as lacking faith (even though she does not report switching her adherence to a different gospel). If a gospel writer were writing her story as that of a follower of Christ, then she might appear under option (ii), as someone who had faith, but not perfect faith, or even under option (iii), as someone whose life became a triumphant exemplar of faith despite her fears and doubts.

That generosity and tolerance of complexity and human imperfection which narrative allows is one of the reasons why people of faith continue to find the gospels inspiring and enriching. It prompts a further question, what pastoral implications there might be for the practice of faith by the Church in the modern world, if it were to reclaim the ideas and practices of faith that dominated early churches. That, and other questions of contemporary significance, however, are beyond the scope of this discussion. $^{1}$

\footnotetext{
${ }^{1}$ I am grateful to the organizers of the 2017 Pacific Division of the American Philosophical Association for including in their programme the panel discussion on which these papers are based, to Professor Daniel Howard-Snyder for organizing the panel, and to Professor Michael Pace for chairing it.
} 


\section{References}

Ashton, J. (1991). Understanding the Fourth Gospel. Oxford: Oxford University Press.

Barton, J. (2014). Ethics in Ancient Israel. Oxford: Oxford University Press.

Howard-Snyder, D. (2013). Propositional faith: What it is and what it is not. American Philosophical Quarterly, 50, 357-372.

Howard-Snyder, D. (2017). Markan Faith. International Journal for Philosophy of Religion, 81(1), 31-60.

McKaughan, D. J. (2017). On the Value of Faith and Faithfulness. International Journal for Philosophy of Religion, 81(1), 7-29.

Morgan, T. (2015). Roman Faith and Christian Faith. Oxford: Oxford University Press.

Rice, R., McKaughan, D. and Howard-Snyder, D. (2017). Guest editorial preface. International Journal for Philosophy of Religion 81 (1), 1-6.

\footnotetext{
${ }^{i}$ Does this change helps to explain why Jerome translates pisteuein by credere rather than fidere, as Prof. McKaughan suggests? I suspect that it does not: credere (from Indo-European çrad or çrat, 'trust') is standard for 'to trust' in classical Latin and widely treated as the verbal form of fides (Morgan 2015, chh. 1-4, passim). Fidere is rare and largely poetic in the simple form (though confidere is common in prose). Jerome, who writes good classicizing Latin, is therefore likely simply to be using the standard classical verb for 'to trust'. ii Arguing that apistoi are non-community members, not simply Christians with different views, see Morgan 2015, 234-41.
} 